\title{
ARTICLE \\ Seasonal shift in the taxonomic diversity of rocky reef fishes in the southwestern Gulf of California
}

\author{
Variación estacional de la diversidad taxonómica de los peces de \\ arrecifes rocosos en el suroeste del Golfo de California

\section{Emelio Barjau-González' ${ }^{1}$ Jesús Rodríguez-Romero ${ }^{2 *}$, Felipe Galván-Magaña ${ }^{3}$ and Minerva Maldonado-García ${ }^{2}$}

\author{
${ }^{1}$ Departamento Académico de Ciencias Marinas y Costeras, Universidad Autónoma de Baja California Sur (UABCS), Apdo. Postal 19, \\ La Paz, Baja California Sur, C.P. 23080, México \\ ${ }^{2}$ Centro de Investigaciones Biológicas del Noroeste (CIBNOR), Apdo. Postal 128, La Paz, Baja California Sur, C.P. 23000, México. \\ *Corresponding author: jrodri@cibnor.mx \\ ${ }^{3}$ Instituto Politécnico Nacional, Centro Interdisciplinario de Ciencias Marinas, Av. IPN s/n. La Paz, Baja California Sur, México. C.P. \\ 23000 México
}

\begin{abstract}
Resumen.- En el suroeste del Golfo de California se presentan capturas de peces de importancia comercial; sin embargo hay pocos estudios relacionados con la diversidad taxonómica de los peces en el área. Se determinaron los cambios en la diversidad taxonómica de la comunidad de peces en 8 localidades cercanas a Bahía de La Paz durante el periodo marzo 2002-abril 2003. Se analizaron los cambios estacionales en la diversidad de peces de arrecife rocoso considerando la distancia taxonómica entre especies de peces utilizando la diversidad alfa, promedio alfa, beta y gama, así como la distintividad taxonómica (TD D*), y el índice promedio de distintividad taxonómica (AvTD D+). Se realizaron censos visuales submarinos en 48 transectos, de $100 \times 5 \mathrm{~m}$ $\left(500 \mathrm{~m}^{2}\right)$ a $5 \mathrm{~m}$ de profundidad, en el horario diurno de 09:00 to 16:00 h. Se observaron 2 temporadas climáticas; una estación fría con una temperatura de $22,57^{\circ} \mathrm{C}$, y una temporada cálida con temperatura promedio de $27,09^{\circ} \mathrm{C}$. Se contabilizaron 24.633 peces de 92 especies y 67 géneros. De acuerdo con los resultados del promedio de los índices de diversidad de alfa, beta y gama, agosto fue el mes con mayor diversidad $(19,5,40,5$ y 60 especies, respectivamente), mientras que diciembre tuvo la menor diversidad $(20,6,27,4$ y 48 especies, respectivamente). En los análisis espaciales del TD y AvTD no se presentaron diferencias significativas, mientras que en el análisis estacional de los índices, se presentaron diferencias significativas. Estas diferencias en ambos índices podrían ser debido a que la localidad El Guano tiene mayor impacto de actividades humanas.
\end{abstract}

Palabras clave: Diversidad taxonómica, peces de arrecife, Golfo de California

\begin{abstract}
The southwestern Gulf of California has high-value commercial fisheries; however, there are few studies of the taxonomic diversity of fish in this area. Surveys of taxonomic diversity of the fish assemblage at 8 localities near the shore of Bahía de La Paz were undertaken from March 2002 to April 2003. Seasonal changes in diversity of rocky reef fish were analyzed, including taxonomic distance among fish species, using the alpha, alpha average, beta, and gamma diversity indices, the taxonomic distinctness index (TD D*), and the average taxonomic distinctness index (AvTD D+). Submarine visual censuses were carried out along 48 transects measuring $100 \times 5 \mathrm{~m}\left(500 \mathrm{~m}^{2}\right)$ at $5 \mathrm{~m}$ average depth from 09:00-16:00 h. Two seasons were studied: winter with an average temperature of $22.57^{\circ} \mathrm{C}$, and summer with an average temperature of $27.09^{\circ} \mathrm{C} .24,633$ fishes, belonging to 92 species and 67 genera were recorded. According to the alpha average, beta, and gamma diversity indices, August had the highest diversity $(19.5,40.5$, and 60 species, respectively), and December had the lowest diversity $(20.6,27.4$, and 48 species, respectively). Spatial analysis of TD and AVTD were not significantly different, and analysis by season of these indices was not significant different. Greater anthropogenic impact would cause differences in TD and AvTD found at El Guano compared with other locations.
\end{abstract}

Key words: Taxonomic diversity, reef fish, Gulf of California

\section{INTRODUCTION}

Fish are the most species-rich group among vertebrates in Mexico. According to Thomson et al. (2000), in the Gulf of California a total of 822 fish species have been recorded, 92 of which are endemic, representing approximately $75.5 \%$ of the 1,088 coastal fish species known for the eastern tropical Pacific
(Robertson \& Allen 2002).

There are no previous studies that consider the taxonomic diversity of rocky reef fish of the coastal zone of Bahía de La Paz, despite the bay's importance for fisheries, eco-tourism, and mining. The bay is also frequently used by many ships 
entering and leaving the city and port of La Paz. In some studies on fish community structure, species richness or species diversity ( $\alpha$ diversity) has been used as a parameter (Magurran 1988, 2004). However, this taxonomic richness underestimates true real taxonomic richness (Griffiths 1997).

Species diversity or richness is hard to relate to productivity or to disturbances in ecosystems because the relationship between productivity and diversity is controversial (Grace 1999, Mackey \& Currie 2001, Mittelbach et al. 2001). For this reason, community richness has not been used as an indicator of disturbance in applied ecology (Drobner et al. 1998). The classical diversity indices, such as the Shannon index, associated with Pielou's equity index or Simpson's index, have been used in ecology to measure environmental impacts on ecosystems (Coleman et al. 1997, Pires et al. 2000). Some authors have criticized these indices, as they fail to discriminate among communities or detect changes in the community (Cairns \& Pratt 1993, Gray 2000, Lydy et al. 2000, Barjau-González et al. 2012a).

To determine the taxonomic diversity of the rocky reef fish community along the coast of the bay, variation in taxonomic diversity was based on taxonomic distance among species, using the taxonomic distinctness index (TD $\Delta^{*}$ ) and average taxonomic distinctness index (AvTD $\Delta+$ ).

\section{MATERIALS AND METHODS}

\section{STUDY AREA}

Bahía de La Paz is on the southeastern side of the Baja California Peninsula. It has an elliptical shape, with its main axis running north-northwest to south-southeast. It is limited on the west and south by land, and on the north and east by the Gulf of California and by the Isla Espíritu Santo and Isla Partida (Álvarez-Arellano et al. 1997). The bay is about $90 \mathrm{~km}$ long by $60 \mathrm{~km}$ wide, encompassing $4,500 \mathrm{~km}^{2}$. There are 2 entrances that connect the bay with the Gulf of California: Boca Grande to the northeast and Boca Chica or San Lorenzo Channel to the east. At the southeastern edge of Boca Grande are Los Islotes, and to the northwest is Punta Mechudo, on the peninsula, where there is a hydrodynamic difference with the San José Channel (Jiménez-Illescas et al. 1997). Sampling locations (Fig. 1) are about $90 \%$ rocky reefs, composed of rocks and sand.

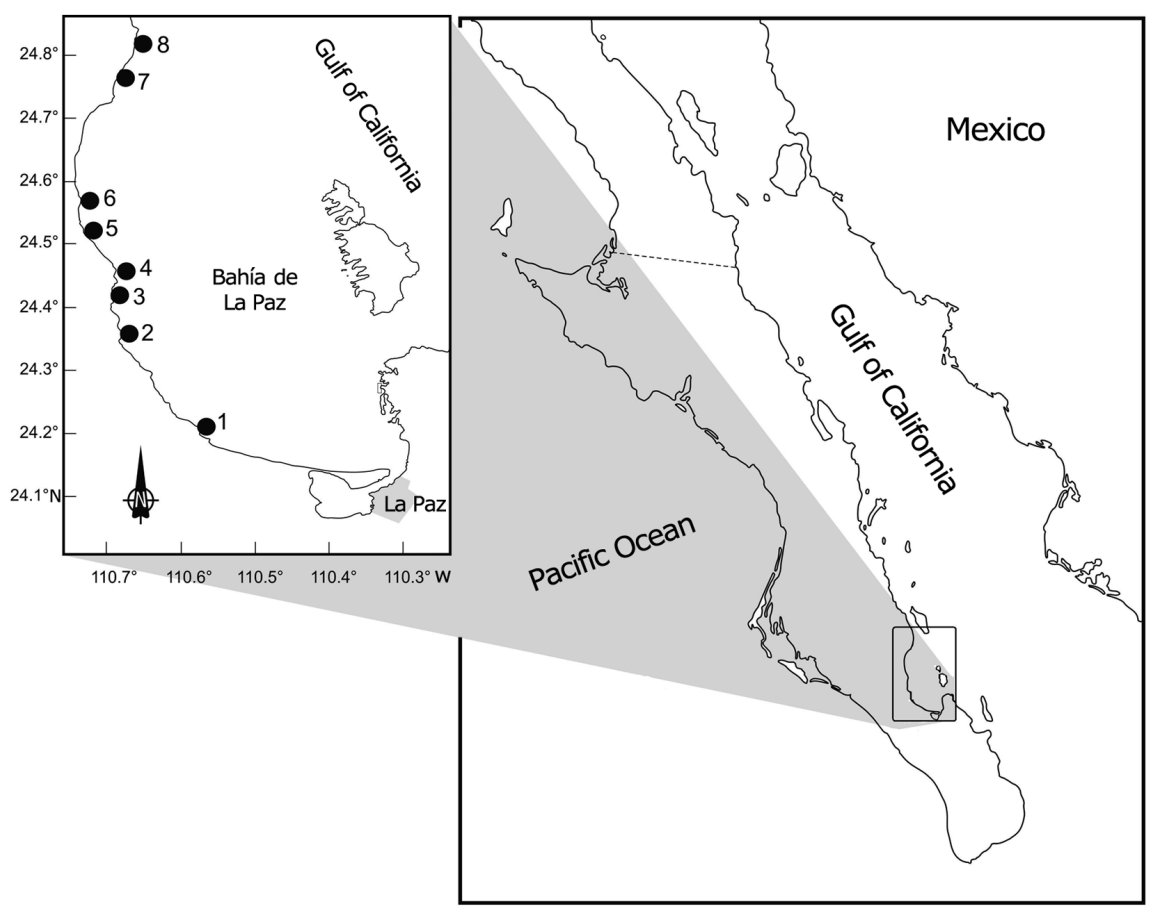

Figure 1. Sampling stations along the coast of Bahía de La Paz: (1) Las Pacas, (2) Piedra Bola, (3) San Juan de la Costa, (4) Tarabillas, (5) El Guano, (6) El Cobre, (7) Portugués, and (8) Mechudo / Área de muestreo incluyendo localidades en la costa de la Bahía de La Paz: (1) Las Pacas, (2) Piedra Bola, (3) San Juan de la Costa, (4) Tarabillas, (5) El Guano, (6) El Cobre, (7) Portugués, y (8) Mechudo 
Sampling trips were carried out in April, June, August, October, and December 2002, and March 2003, at 8 locations along the peninsular shore of the bay. A total of 48 visual surveys were carried out to determine taxonomic diversity of fish. Six surveys were carried out per location by free diving along 100 $\times 5 \mathrm{~m}$ belt transects (Rodríguez-Romero et al. 2005, BarjauGonzález 2012, Barjau-González et al. 2012a). Sampling was carried out between 09:00 $\mathrm{h}$ and 16:00 h. Geographic coordinates of sampling sites were recorded using GPS. Species, frequency of occurrence, and number of organisms were recorded on acrylic sheets using graphite pencils.

At each location, temperature $\left( \pm 0.1^{\circ} \mathrm{C}\right)$ and water oxygen content $\left( \pm 0.1 \mathrm{mg} \mathrm{L}^{-1}\right)$ were measured (model 55, YSI, Yellow Springs, OH). Salinity ( \pm 1 psu) was measured with a refractometer. These variables were recorded after each survey. For the alpha, beta, and gamma diversity indices, data of presence/absence were used. For taxonomic diversity, the indices of taxonomic distinctness index (TD) and average taxonomic distinctness index (AvTD) were used (Clarke \& Warwick 2001). For TD and total abundance, the data were standardized (Clarke \& Warwick 2001). For AvTD, presence/ absence data were used.

Species affinity was measured through a similarity analysis using the Bray-Curtis similarity coefficient (SIMPER: Clarke \& Warwick 2001). Software for the analyses was Primer6, PrimerE, and Permanova+ 1.0.2 and STATISTICA 8.0. The following taxonomic diversity analysis methods were used:

- Alpha diversity: Also known as local or point diversity. The number of species at each location was used.

- Average alpha diversity: Average of all alpha diversities by location and month.

- Beta diversity: Measures the differences (turnover) between species at 2 locations, 2 community types, or two landscapes; the Whittaker (1972) index was used.

- $\beta=\gamma-\bar{\alpha}$, where: $\beta=$ beta diversity, $\gamma=$ gamma diversity, $\bar{\alpha}=$ alpha average.

- Gamma diversity: Number of species at all sites or communities that make up a landscape.

- Taxonomic distinctness index (TD $\Delta^{*}$ ) (Clarke \& Warwick 1999): This index measures taxonomic distance and species richness, using total species abundance. This index is a more precise measure of biodiversity, since it incorporates qualitative, as well as quantitative aspects of the fauna or flora (Clarke \& Warwick 1999).

- Average taxonomic distinctness index (AvTD $\Delta+)$ (Clarke \& Warwick 2001): This index measured richness and taxonomic distance of each species pair, defined through a Linnaean classification tree.

In the last 2 indices, each hierarchical taxonomic level is assigned a discrete and proportional value in a scale from 0 to 100. These indices are independent of sample size and do not need data normality. To calculate these indices, 6 hierarchical levels were used: species, genus, family, order, class, and phylum.

\section{ReSUltS}

We made 48 visual surveys every 2 months to 8 locations (Fig. 1). Surveys were carried out at a depth of about $5 \mathrm{~m}$. Water temperature was the most variable condition, based on currents and winter during April, March, and June $\left(\sim 23^{\circ} \mathrm{C}\right)$ and currents and summer during August, October, and December $\left(\sim 27^{\circ} \mathrm{C}\right)$. December was included in the summer season because its mean temperature was significantly higher than the winter mean (Fig. 2 and Table 1). Salinity and dissolved oxygen were not significantly different by location $(P>0.05)$, but there were differences by season $(P<0.05)$ (Table 1$)$. There were 24,663 fish recorded, belonging to 92 species, 67 genera, and 40 families. The families with the most species were: Pomacentridae (8), Labridae (7), Haemulidae (6), Serranidae (6), Scaridae (5), Lutjanidae (4), and Tetraodentidae (4).

The alpha diversity index was not significant by location $\left(\mathrm{F}_{(7.40)}=1.594, P=0.1653\right)$ or month $\left(\mathrm{F}_{(5.42)}=0.5572, P=\right.$ $0.7320)$. The average by location was 19 species; the highest was at San Juan de la Costa ( 20 species) and the lowest was at Las Pacas (14 species). The most species by month was March (21 species) and the least was October (18 species). In general, this index indicates that there was no defined pattern. During summer, only December was above the general average (21 species), and during winter, March had more species. April and June were below average (Table 1).

Beta and gamma diversity had the highest counts in August (41 and 60 species) and the lowest in December (27 and 48 species), which indicates that in August there was a higher percentage of species turnover (ß) than in December (Fig. 3).

The TD calculated from total abundance data had statistically significant differences $\left(\mathrm{F}_{(5.42)}=5.845, P=0.0003\right)$. The average was $\mathrm{s}=53.68$, the highest count was recorded in June $(\mathrm{s}=$ $56.69)$, and the lowest in October $(\mathrm{s}=51.88)$ (Table 1). Analysis by location did was not significant different $\left(\mathrm{F}_{(7.40)}=0.5197, P=0.8142\right)$. The highest count was at Las Pacas ( $\mathrm{s}=55.83)$, and the lowest count was at Punta Mechudo $(\mathrm{s}=53.68)($ Table 1$)$.

The AvTD had statistically significant differences $\left(\mathrm{F}_{(5.42)}=\right.$ $3.7193, P=0.0071)$, and a general average of $\mathrm{s}=55.80$. The 


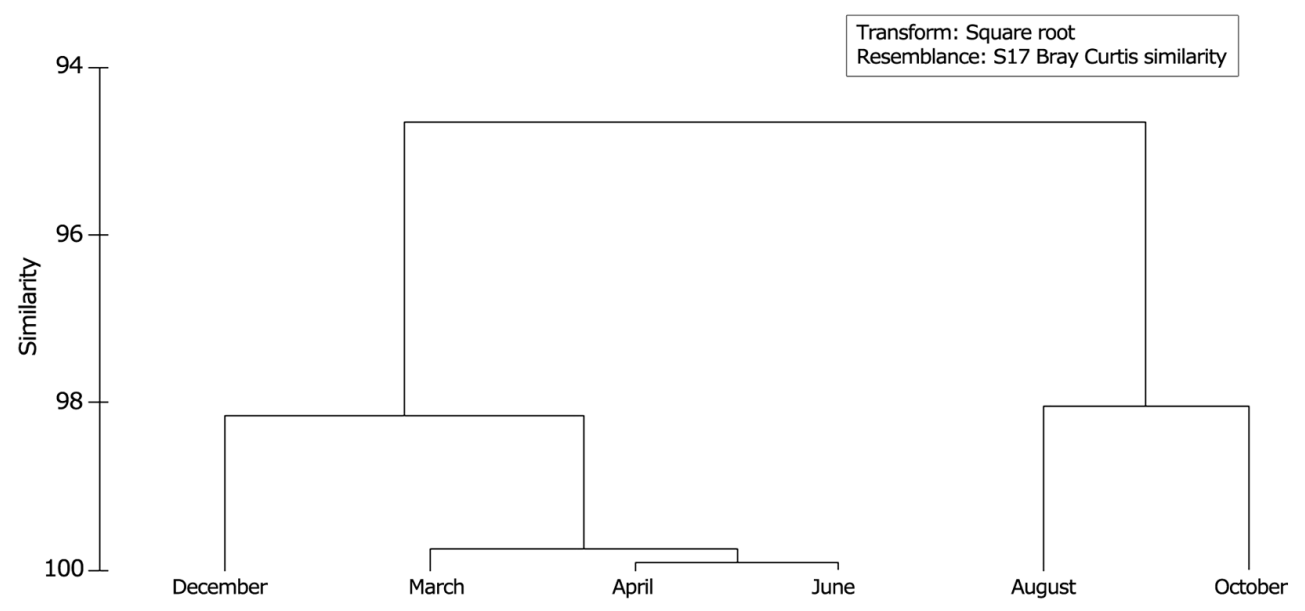

Figure 2. Dendrogram of water temperature along the coast of Bahía de La Paz / Dendrograma mensual de la temperatura del agua en la zona costera de la Bahía de La Paz

Table 1. Relationship of physical, chemical, and taxonomic parameters by location, month and season / Parámetros físicos, químicos y taxonómicos mensuales y estacionales en cada localidad

\begin{tabular}{lcccccccc}
\hline & $\mathrm{T}^{\circ} \mathrm{C}$ & $\%$ o & $\mathrm{OD}$ & $\alpha$ & $\bar{\alpha}$ & $\beta$ & $\Delta+$ & $\Delta^{*}$ \\
\hline Location & & & & & & & & \\
$\quad$ Las Pacas & 24.30 & 35.08 & 5.74 & 35 & 13.83 & 21.167 & 59.292 & 55.835 \\
Piedra Bola & 24.95 & 35.02 & 5.70 & 46 & 18.16 & 27.833 & 56.568 & 53.73 \\
San Juan & 25.30 & 35.03 & 6.05 & 50 & 22 & 28 & 54.839 & 52.666 \\
Tarabilla & 25.08 & 35.02 & 6.26 & 43 & 19.5 & 23.5 & 55.735 & 54.154 \\
ElGuano & 25.03 & 35.02 & 6.33 & 46 & 21.5 & 24.5 & 53.586 & 53.664 \\
ElCobre & 24.72 & 35.00 & 6.33 & 41 & 20 & 21 & 54.466 & 53.231 \\
Portugués & 24.45 & 34.98 & 5.74 & 49 & 20 & 29 & 55.846 & 52.994 \\
Mechudo & 24.30 & 35.08 & 5.26 & 44 & 19.16 & 24.833 & 55.798 & 53.694 \\
Month & & & & & & & & \\
April & 22.63 & 35.03 & 3.68 & 55 & 18 & 37 & 56.159 & 53.989 \\
June & 22.68 & 35.06 & 7.33 & 53 & 18.5 & 34.5 & 58.519 & 56.691 \\
August & 29.63 & 35.09 & 5.70 & 60 & 19.5 & 40.5 & 54.481 & 52.176 \\
October & 27.39 & 35.04 & 5.67 & 53 & 17.87 & 35.125 & 54.016 & 51.881 \\
December & 24.26 & 34.96 & 6.48 & 48 & 20.62 & 27.375 & 54.984 & 52.624 \\
March & 22.41 & 35.00 & 6.71 & 54 & 21.12 & 32.875 & 56.663 & 54.749 \\
Season & & & & & & & & \\
Winter mean & 22.57 & 35.03 & 5.9 & 54 & 19.208 & 23 & 56.995 & 54.252 \\
Summer mean & 27.09 & 35.00 & 6.37 & 48 & 19.333 & 21.333 & 55.646 & 53.234 \\
\hline
\end{tabular}

Temperature $\left(\mathrm{T}^{\circ} \mathrm{C}\right)$, salinity $(\%)$, dissolved oxygen (DO), Alpha diversity $(\alpha)$, Average alpha diversity $(\bar{\alpha})$, Beta diversity $(\beta)$, Taxonomic distinctness $\left(\Delta^{*}\right)$, and average taxonomic distinctness $(\Delta+)$ 


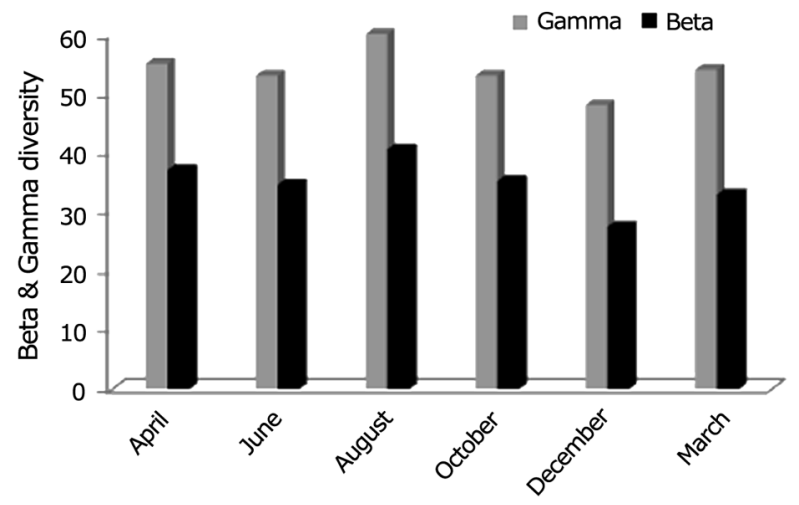

Figure 3. Beta and gamma diversity of fish census along the coast of Bahía de La Paz Bay/ Diversidad beta y gamma en los censos de peces en la zona costera de la Bahía de La Paz highest count was in June ( $\mathrm{s}=58.51)$, and the lowest in October $(s=54.01)$ (Table 1). There were no statistically significant differences among locations $\left(\mathrm{F}_{(7.40)}=1.5675, P=0.1733\right)$. The highest count was at Las Pacas ( $\mathrm{s}=59.29$ ) and the lowest count was at El Guano ( $\mathrm{s}=53.58)$ (Table 1$)$.

Figure 4 shows the most contrasting values recorded for AvTD and species number. Las Pacas and Portugués were at the upper limit of $95 \%$ confidence interval of the tunnel. Tarabillas is placed slightly above the tunnel average. Cobre, Mechudo, Piedra Bola, and San Juan de la Costa are located slighted below the same average. El Guano is located very close to the lower limit line of the $95 \%$ confidence interval.

Figure 5 shows lambda values contrasted with species number. Las Pacas and Portugués are located at the upper limit of the confidence interval. Mechudo, Tarabillas, and Piedra Bola are located slightly above the average. San Juan de la Costa is slightly below the average; El Guano is located on the lower line of the $95 \%$ confidence interval.
Figure 4. Average taxonomic distinctness for fish species at stations along the coast of Bahía de La Paz: Las Pacas, Piedra Bola, San Juan de la Costa, Tarabillas, EI Guano, El Cobre, Portugués, and Mechudo / Distintividad taxonómicas de las especies de peces en la zona costera de la Bahía de La Paz: Las Pacas, Piedra Bola, San Juan de la Costa, Tarabillas, El Guano, El Cobre, Portugués, y Mechudo

Figure 5. Taxonomic distinctness with Lambda averages of fish species at stations along the coast of Bahía de La Paz: Las Pacas, Piedra Bola, San Juan de la Costa, Tarabilla, El Guano, El Cobre, Portugués, and Mechudo / Diagrama de distintividad taxonómica utilizando promedios de Lambda en los peces censados en Bahía de La Paz: Las Pacas, Piedra Bola, San Juan de la Costa, Tarabillas, El Guano, El Cobre, Portugués, y Mechudo
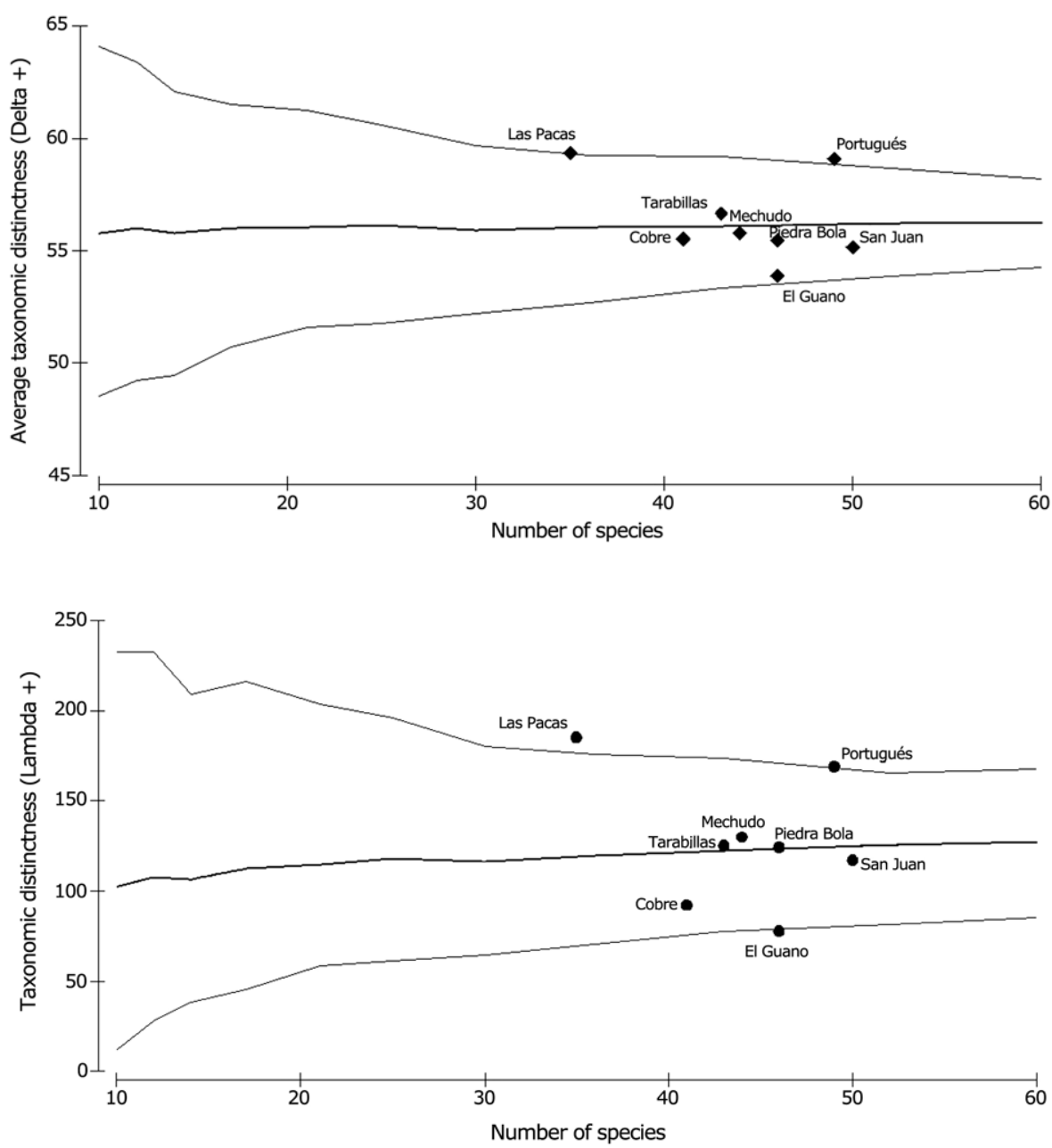


\section{Discussion}

The southwestern part of the Gulf of California has high commercial importance because this ecosystem has species richness of ecological, commercial, and touristic importance. The fish species on the hard substrata of the coast included 92 fish conspicuous and permanent species, as well as seasonal species. Of the 281 reef fish species in the Gulf of California (Thomson et al. 2000), about 33\% were observed in the study area.

In other areas of the Gulf of California, such as Islas San José, Cerralvo, and Espíritu Santo, as well as the eastern coast of the bay, water temperature, as well as the diversity of the surrounding fauna and flora on the reef substrate, contribute to increased fish abundance and diversity. This structural character is present in other tropical and subtropical ecosystems of the southern Gulf of California (Jiménez-Gutiérrez 1999, RodríguezRomero et al. 2005, Barjau-González et al. 2012a). Water temperature, habitat type, and areas for feeding, breeding, and protection in rocky reefs increase abundance, concentration, and species richness of fish species (Pérez-España et al. 1996, Galván-Piña et al. 2003, Dominici-Arosamena \& Wolff 2006, Alvarez-Filip et al. 2011, Barjau-González et al. 2012a).

Structural changes in species richness between seasons is tied to water temperature, type of substrate, and surrounding flora (Rodríguez-Romero et al. 1998, 2005; Galván-Magaña et al. 2000, Barjau-González et al. 2012a). Studies of community structure of conspicuous reef fish in several ecosystems of the southern Gulf of California, mainly within bays, surrounding islands, estuaries, and reef areas include Pérez España et al. (1996), Villarreal-Cavazos et al. (2000), AburtoOropeza \& Balart (2001), Viesca-Lobatón (2003), ÁlvarezFilip (2004), Campos-Dávila et al. (2005), Rodríguez-Romero et al. (2005), Álvarez-Filip et al. (2006), Villegas-Sánchez et al. (2009), Barjau-Gonzalez et al. (2012a) and Galván-Villa (2015).

The Shannon Index of species richness and Pielou's equity Index were used in those studies; for the bay, there are no previous studies that used the alpha, beta, and gamma diversity indices, as well as taxonomic distinctness indices, as components of species richness.

The alpha diversity index did not indicate any statistical differences between the highest count at San Juan de la Costa and the lowest count at Las Pacas. The alpha diversity index reflects ecological relations (Halffter \& Moreno 2005) and would allow inferring why this variation occurs among locations. The coastal zone of the bay is subtropical with temperate influence and changing conditions related to summer and winter that, to some extent, influence the dynamics of communities and taxonomic diversity (Barjau-González et al. 2012b). Beta diversity is a measure of the turnover in species between 2 points when counts are taken in different places at the same time or when counts are taken in the same place but at different seasons (Halffter \& Moreno 2005). There was greater species turnover at Portugués and lower turnover at Las Pacas and Cobre. These results are similar to Whittaker (1975) who refers to species as taxonomic entities and not to species numbers. Cornell \& Lawton (1992) suggest that beta diversity is a link between alpha and gamma diversities. Our results agree with Koleff \& Gaston (2002) who measured spatial turnover (beta diversity) in terms of species changes, which is also presented in our study by testing the influence between beta diversity, and alpha and gamma diversities.

The gamma diversity or regional species component is a consequence of historic-geographic processes that act on a mesoscale, which is influenced by alpha and beta diversities. This is the level where human actions, such as change and fragmentation of communities, have their most important effect, in terms of species permanence or extinction. These effects are exaggerated or misinterpreted by the analysis of species richness (Halffter \& Moreno 2005).

Most species (48\%) in this area show affinity with the Panama Province, which suggests that they share a similar environment and biogeographic conditions. This agrees with Halffter \& Moreno (2005).

The AvTD $(\Delta+)$ showed statistical differences among months $(P<0.05)$; the highest count was recorded in June, which shows that average taxonomic distances among species were not taxonomically close. This could be explained by June as a transition month between winter and summer (Aguirre-Bahena 2007).

Studies near Bahía de La Paz found different results. AlvarezFilip \& Reyes-Bonilla (2006) used this index in the Cabo Pulmo reef to the south and found differences with depths $\left(\mathrm{F}_{1.35}=4.58\right.$; $P=0.04)$ but not among seasons $\left(\mathrm{F}_{1.35}=0.43 ; P=0.52\right)$. They compared 2 years (1987 and 2003) and did not find statistically significant differences between those years $(P<0.01)$.

Reyes-Bonilla \& Alvarez-Filip (2008), in another study of the Cabo Pulmo reef, using 9 years of data, did not find differences among years $(\mathrm{F}=1.7, P=0.09)$. These studies differ from our present study because of the range of years and comparisons among years, as well as water depth and periodicity of observations.

In our study, this index was used to compare locations, and did not show statistical differences. El Guano, at the lower limit of the confidence interval, also had the lowest count. This can 
be explained because the location has been disturbed by overfishing, and mining of phosphate rock in the vicinity. This resembles Sosa-López et al. (2005) who studied the Laguna de Términos in the State of Campeche. Variations in the taxonomic structure of the lagoon were based fishing activity, contaminants, and changes in hydrological conditions.

Taxonomically close species use similar habitats and resources. Warwick \& Clarke (2001) find that AvTD can discriminate among habitats with low distinctness values and AvTD counts are closely associated with trophic levels. Variations in AvTD among locations result from having a few trophic levels. Saldívar-Lucio (2010) found long-term changes of reef fish species at Cabo Pulmo and similar AvTD counts as those in our study.

The spatial analysis of the TD indicated no statistically significant differences in the bay, but again, El Guano was at the lower limit of the confidence interval, which indicates that this location has been altered. The remaining locations were close to the average, and two locations were on the upper limit of the confidence interval, indicating that these two locations are well conserved. This agrees with the position of Sosa-López et al. (2005) who argues that high TD values indicate higher conservation values. The Bahía de La Paz, in general, has these characteristics, with high average values above 50 units, indicating that the bay is a relatively healthy ecosystem ecologically, taxonomically, and biologically.

\section{ACKNOWLedGMENTS}

Funding was provided by CIBNOR under project 'Estructura y ecología trofica de peces en el Noroeste de México'. Mario Costa of CIBNOR and Mario Silva provided underwater surveys. E.B.G. received support from the Universidad Autónoma de Baja California Sur. F.GM. is a fellow of Instituto Politécnico Nacional (COFAA and EDI). English editing services were provided by Ira Fogel of CIBNOR. To Gerardo R. Hernández García for help to draw figures.

\section{LITERATURE CITED}

Aburto-Oropeza O \& EF Balart. 2001. Community structure of reef fish in several habitats of a rocky reef in the Gulf of California. Marine Ecology 22(4): 283-305.

Aguirre-Bahena F. 2007. Cambios temporales en los componentes y los flujos de la materia en hundimiento en la cuenca Alfonso, Bahía de La Paz, durante el periodo 20022005. Doctoral Thesis, CICIMAR-IPN, La Paz, 102 pp.

Álvarez-Arellano AD, H Rojas-Soriano \& J PrietoMendoza. 1997. Geología de la Bahía de La Paz y áreas adyacentes. En: Urbán RJ \& M Ramírez (eds). La Bahía de La Paz, investigación y conservación, pp. 13-29. UABCSCICIMAR-SCRIPPS, La Paz.
Alvarez-Filip L. 2004. Influencia del hábitat sobre la asociación de peces en el arrecife coralino de Cabo Pulmo, B.C.S., México. Master's Thesis, CICESE, Ensenada, BCS, Mexico, 102 pp.

Alvarez-Filip L \& H Reyes-Bonilla. 2006. Comparison of community structure and functional diversity of fishes at Cabo Pulmo coral reef, western Mexico between 1987 and 2003. Proceedings of 10th International Coral Reef Symposium 2: 16225.

Alvarez-Filip L, H Reyes-Bonilla \& LE Calderon-Aguilera. 2006. Community structure of fishes in Cabo Pulmo Reef, Gulf of California. Marine Ecology 27: 253-262.

Alvarez-Filip L, JA Gill \& NK Dulvy. 2011. Coral reef architectural complexity influences fish community and food web structure. Ecosphere 2: 118.

Barjau-González E. 2012. Estructura comunitaria y diversidad taxonómica de los peces en la Bahía de la Paz y la Isla San José, Golfo de California. Doctoral Thesis, CIBNOR, La Paz, BCS, Mexico, 149 pp.

Barjau-González E, J Rodríguez-Romero, F Galván-Magaña \& J López-Martínez. 2012a. Estructura temporal y espacial de la comunidad de peces arrecifales de la Isla San José, Golfo de California, México. Revista de Biología Tropical 60(2): 649-667.

Barjau-González E, J Rodríguez-Romero, F Galván-Magaña \& J López-Martínez. 2012b. Changes in the taxonomic diversity of the reef fish community of San Jose Island, Gulf of California, Mexico. Biodiversity and Conservation 21: 3543-3554.

Cairns JJ \& JR Pratt. 1993. A history of biological monitoring using benthic macroinvertebrates. In: Rosenberg DM \& VH Resh (eds). Freshwater biomonitoring and benthic macroinvertebrates, pp. 10-27. Chapman and Hall, New York.

Campos-Davila L, VH Cruz-Escalona, F Galván-Magaña, LA Abítia-Cárdenas, FJ Gutiérrez-Sánchez \& EF Balart. 2005. Fish assemblages in a Gulf of California marine reserve. Bulletin of Marine Science 77: 347-362.

Clarke KR \& RM Warwick. 1999. The taxonomic distinctness measure of biodiversity: weighting of step lengths between hierarchical levels. Marine Ecology Progress Series 184: 21-29.

Clarke KR \& RM Warwick. 2001. A further biodiversity index applicable to species lists: variation in taxonomic distinctness. Marine Ecology Progress Series 216: 265-278.

Coleman N, ASH Gason \& GCB Poore. 1997. High species richness in the shallow marine waters of south-east Australia. Marine Ecology Progress Series 154: 17-26.

Cornell HV \& JH Lawton. 1992. Species interactions, local and regional processes and limits to the richness of ecological communities: A theoretical perspective. Journal of Animal Ecology 61: 1-12.

Dominici-Arosamena A \& M Wolff. 2006. Reef fish community structure in the Tropical Eastern Pacific (Panama): living on a relatively stable rocky reef environment. Helgoland Marine Research 60: 287-305. 
Drobner U, J Bibby, B Smith \& JB Wilson. 1998. The relation between community biomass and evenness, what does community theory predict and can these predictions be tested? Oikos 82: 295-302.

Galván-Magaña F, LA Abítia-Cárdenas FJ GutiérrezSánchez \& J Rodríguez-Romero. 2000. The distribution and affinities of the shore fishes of Baja California Sur lagoons. In: Munawar M, S Lawrence, IF Munawar \& D Malley (eds). Aquatic ecosystems of Mexico: Status and scope, pp. 383-398. Ecovision World Monograph series. Backhuys Publishers, Leiden.

Galván-Piña VH, F Galván-Magaña, LA Abítia-Cárdenas, FJ Gutiérrez-Sánchez \& J Rodríguez-Romero. 2003. Seasonal structure of fish assemblages in rocky and sand habitats in Bahía de La Paz, México. Bulletin of Marine Science 72(1): 19-35.

Galván-Villa CM. 2015. Reef fish assemblage structure of three marine protected areas from the Mexican Pacific. Ecosistemas y Recursos Agropecuarios 2(4): 69-86.

Grace JB. 1999. The factors controlling species density in herbaceous plant communities, an assessment. Perspectives in Plant Ecology, Evolution and Systematics 2: 1-28.

Gray JS. 2000. The measurement of marine species diversity, with an application to the benthic fauna of the Norwegian Shelf. Journal of Experimental Marine Biology and Ecology 250: 23-49.

Griffiths D. 1997. Local and regional species richness in North American lacustrine fish. Journal of Animal Ecology 66: 4956.

Halffter G \& CE Moreno. 2005. Significado biológico de las diversidades Alfa, Beta y Gamma. En: Halffter G, J Soberón, P Koleff \& A Melic (eds). Monografías Tercer Milenio 4: 518. S.E.A., Zaragoza.

Jiménez-Gutiérrez SV. 1999. Abundancia y estructura comunitaria de peces de arrecifes rocosos en la zona de Isla Cerralvo, B.C.S., México. Tesis de Maestría, CICIMAR/ IPN, La Paz, BCS, Mexico, 91 pp.

Jiménez-Illescas A, M Obeso \& D Salas de León. 1997. Oceanografía física de la Bahía de La Paz, B.C.S. En: Urbán RJ \& M Ramírez (eds). La Bahía de La Paz, Investigación y Conservación, pp. 31-41. UABCS/CICIMAR/SCRIPPS, La Paz.

Koleff P \& KJ Gaston. 2002. The relationships between local and regional species richness and species turnover. Global Ecology and Biogeography 11: 363-375.

Lydy MJ, CG Crawford \& JW Frey. 2000. A comparison of selected diversity, similarity, and biotic indices for detecting changes in benthic-invertebrate community structure and stream quality. Archives of Environmental Contamination and Toxicology 39: 469-479.
Mackey RL \& DJ Currie. 2001. The diversity-disturbance relationship, is it generally strong and peaked? Ecology 82 : 3479-3492.

Magurran AE. 1988. Ecological diversity and its measurement, 250 pp. Princeton University Press, Princeton.

Magurran AE. 2004. Measuring biological diversity, 256 pp. Blackwell Publishing, Oxford.

Mittelbach GG, CF Steiner, SM Scheiner, KI Gross, HL Reynolds, RB Waide, MR Willig, SI Dodson \& L Gough. 2001. What is the observed relationship between species richness and productivity? Ecology 82: 2381-2396.

Pérez-España EH, F Galván-Magaña \& LA AbítiaCárdenas. 1996. Variaciones temporales y espaciales en la estructura de la comunidad de peces de arrecifes rocosos del suroeste del Golfo de California, México. Ciencias Marinas 22(3): 273-294.

Pires AM, IG Cowx \& MM Coelho. 2000. Benthic macroinvertebrate communities of intermittent streams in the middle reaches of the Guadiana Basin (Portugal). Hydrobiologia 435: 167-175.

Reyes-Bonilla H \& LAlvarez-Filip. 2008. Long-term changes in taxonomic distinctness and trophic structure of reef fishes at Cabo Pulmo reef, Gulf of California. Proceedings of the 11 th International Coral Reef Symposium, Ft. Lauderadale, 18: 790-794.

Robertson DR \& GR Allen. 2002. Shore fishes of the Tropical Eastern Pacific: an information system. Smithsonian Tropical Research Institute, Balboa. [CD-ROM].

Rodríguez-Romero J, LA Abítia-Cárdenas, F GalvánMagaña, J Arvizu-Martínez \& B Aguilar-Palomino. 1998. Ecology of fish communities from the soft bottoms of Bahía Concepción, México. Archive of Fishery and Marine Research 46(1): 61-76.

Rodríguez-Romero J, AF Muhlia-Melo, F Galván-Magaña, FJ Gutiérrez-Sánchez \& V Gracia-López. 2005. Fish assemblages around Espiritu Santo Island and Espiritu Santo Seamount in the Lower Gulf of California, México. Bulletin of Marine Science 64: 383-390.

Saldívar-Lucio RE. 2010. Cambios a largo plazo en la ictiofauna arrecifal del parque nacional Cabo Pulmo Baja California Sur, México. Master's Thesis, CICIMAR-IPN, La Paz, BCS, México, 146 pp.

Sosa-López A, J Ramos-Miranda, D Flores-Hernández, D Mouillot \& T Do-Chi. 2005. Evidencia de cambios en la diversidad ictiofaunística de la Laguna de Términos, México. JAINA Boletín Informativo 15(1): 7-13.

Thomson DA, LT Findley \& AN Kerstitch. 2000. Reef fishes of the Sea of Cortez, $353 \mathrm{pp}$. University of Texas Press, Austin. 
Viesca-Lobatón C. 2003. Cambios temporales en la estructura de la comunidad de peces de arrecifes rocosos en la parte sur-occidental del Golfo de California. Licenciatura Thesis, UABCS, La Paz, 75 pp.

Villarreal-Cavazos A, H Reyes-Bonilla, B BermúdezAlmada \& O Arizpe-Covarrubias. 2000. Los peces del arrecife de Cabo Pulmo, Golfo de California, México: Lista sistemática y aspectos de abundancia y biogeografía. Revista de Biología Tropical 48: 2-3.

Villegas-Sánchez CA, LA Abítia-Cárdenas, FJ GutiérrezSánchez \& F Galván-Magaña. 2009. Rocky-reef fish assemblages at San José Island, México. Revista Mexicana de Biodiversidad 80: 169-179.
Warwick RM \& KR Clarke. 2001. Practical measures of marine biodiversity based on relatedness of species. Oceanography \& Marine Biology Annual Review 39: $207-$ 231.

Whittaker RH. 1972. Evolution and measurement of species diversity. Taxon 21(273): 213-251.

Whittaker RH. 1975. Communities and ecosystems, 385 pp. MacMillan, New York.

Received 9 April 2015 and accepted 11 November 2015

Editor: Claudia Bustos D. 